\title{
Oral health related habits, knowledge and attittude in children with asthma
}

\author{
Bojana Davidović', Mirjana Ivanović², Dejan Bokonjić3, Svjetlana Janković', Igor Radović', \\ Jelena Lečić1 \\ 'University East Sarajevo, Faculty of Medicine, Dentistry department, Foča, Bosnia and Herzegovina; \\ ${ }^{2}$ Faculty of Dental Medicine, Department of Pediatric and Preventive Dentistry, Belgrade, Serbia; \\ ${ }^{3}$ University Hospital in Foca, Department of Pediatrics, Foča, Bosnia and Herzegovina
}

\begin{abstract}
SUMMARY
Introduction The aim of this research was to determine oral hygiene related habits, knowledge and behavior in children with asthma compared to healthy children.

Methodology This study included 136 children, between 6 to 16 years of age, divided into the two groups. The first group included children with asthma (study group - SG), while the second included healthy children (control group - CG). A questionnaire containing three groups of questions related to oral-hygiene and dietery habits as well as oral health related behaviour in children was prepared.

Results The percentage of children from SG that brush teeth several times a day was $60.2 \%$ compared to $77.2 \%$ of CG children ( $p<0.05$ ). 19.1\% of SG group children versus $38.2 \%$ of CG children brush their teeth longer than 2 minutes $(p<0.05)$. There was no significant difference in the level of knowledge about plaque impact on oral health between the two groups ( $p>0.05$ ). More than half $(52.9 \%)$ of CG respondents regularly visit dentist, while $50.0 \%$ of SG goes regularly $(p<0.01) .51 .5 \%$ of CG children visit the pediatric dentist due to preventive reasons, while SG children goes mainly due to rehabilitation of teeth (42.6\%). The fear of dental procedures is more pronounced in SG compared to CG children $(p<0.001)$.

Conclusion Oral hygiene related habits and oral health behavior were worse in children with asthma, while no difference was found in relation to the knowledge among the observed groups.

Keywords: children; asthma; oral-hygiene habits; knowledge; oral hygiene
\end{abstract}

\section{INTRODUCTION}

Asthma is chronic inflammatory disease of airways, which usually begins in childhood. Once exposed to certain stimuli, airways narrow due to muscle spasm, mucus plugs and swelling of mucous membranes causing limited airflow [1]. It is one of the leading causes of hospitalization in children age.

Asthma treatment aims either to alleviate symptoms or to exhibit antiinflamatory effect. Literature data indicate [2] that some of anti-asthmatic medications affect the composition and the amount of saliva and therefore expose affected persons to increased risk of caries, tooth erosions, increased prevalence of oral mucosa changes, gingivitis, periodontitis, orophageal candidiasis and orofacial irregularities [2]. Therefore, children with asthma require greater attention because they can be considered risky group for developing oral diseases.

Due to oral hygiene importance in childhood many studies have addressed risk factors that can lead to oral diseases. Based on numerous epidemiological studies it has been recognised that parents' oral health related hab- its as well as their lifestyle, are transmitted to children and thus directly and indirectly affect the occurrence of tooth decay [3].

The fear of dental procedures affects large number of people, regardless of age, gender, physical and mental maturity, level of education, economic status, occupation and in children specifically, parents approach towards dental treatment $[4,5]$. "Fear of dentist" is the most common reason for avoiding treatment, causing the absence of adequate dental care, which may lead to deterioration of oral health $[5,6]$.

Patients that have asthma are risk patients in dental office as dental stress and strong smell can cause asthmatic attack. Also, due to close proximity of the upper respiratory tract, patients with chronic respiratory problems such as asthma represent risk patients in dentistry. Acute asthma attacks may be one of the factors that increase fear of dental visits as well as affect oral health related behavioral model of asthmatic children.

The aim of this study is to investigate oral hygiene related habits, knowledge and behavior of children with asthma compared to healthy children. 


\section{MATERIALS AND METHODS}

The research was conducted at the Department of Dentistry, Faculty of Medicine, University of East Sarajevo, according to the recommendations of the Helsinki Declaration and principles of Good Clinical Practice. Parents and children were informed about the purpose of research, and approval for participation was obtained.

This cross sectional study included children between 6 to 16 years of age $(10.49 \pm 3.28)$. A total of 136 children were divided into the two groups. Study group (SG) $(\mathrm{n}=68)$ consisted of children with asthma symptoms. The control group (CG) $(\mathrm{n}=68)$ included healthy children. Asthma diagnosis was established by a competent pediatrician or family medicine physician based on the following criteria: existence of typical asthma symptoms, spirometry findings, reaction to asthma medication (reversibility of obstruction), allergy existence, positive family history and absence of other conditions that may give similar symptoms or signs [1].The study was designed in a way that children from the control group corresponded by gender and age to children from the study group.

For the purpose of this study a questionnaire was created and included three groups of questions: about oral hygiene and dietary related habits, oral health knowledge and established behavioral habits related to dental visits.

Obtained data were processed through standard statistical procedures using statistical program SPSS 19.0 for Windows. To test differences between genders and education level of parents, $\chi 2$ test was used. Values of $\mathrm{p}<0.05$ were considered statistically significant.

\section{RESULTS}

Asthma was more frequently diagnosed in boys (77.9\%) compared to girls $(22.1 \%)(\mathrm{p}<0.05)$ (Figure1). High $(18.4 \%)$ and secondary education (31.6\%) were more prevalent among mothers of children in the CG, compared to primary (4.2\%) or secondary education $(39.7 \%)$ of mothers of $S G$ children $(p<0.05)$ (Figure 2). The difference was not observed in relation to the level of education of fathers in these two groups ( $p>0.05$ ).

Almost $83 \%$ of SG children used only toothbrush and toothpaste for oral hygiene in comparison to the CG children that used mouthwashes (26.5\%) as an adjunct to basic hygienic agents (Table 1). $60.2 \%$ of SG children brushed their teeth several times a day, while that percentage was $77.2 \%$ in the control group. Parents more frequently supervised the CG children while maintaining oral hygiene (28.0\%), compared to the parents of the study group 20.6\%. Almost 15\% of SG group children were not supervised. Both groups consumed cariogenic food and drink, while larger percentage was observed in the study group ( $\mathrm{p}>0.05$ ). Good self-observed oral health was noted at $45.6 \%$ of children in the study and $75.0 \%$ in the control group $(\mathrm{p}<0.001)$ (Table 2$)$.

$52.9 \%$ of children in the control group had frequent checkups with dentist while $50.0 \%$ of study group children occasionally went to dentist $(\mathrm{p}<0.01)$ (Table 3$)$. In- terestingly $7.4 \%$ of SG children have never been to the dentist, compared to $2.9 \%$ of children in the control group. CG children (51.5\%) would visit dentist for preventive reasons while SG children most frequently $(42.6 \%)$ visited dentist for dental treatment. Fear of dental interventions was more pronounced in the study group of children compared to control group $(\mathrm{p}<0.001)$. High percentage of SG children acquired knowledge about oral health importance from parents (55.9), while that prcentage was $61.8 \%$ in CG children (Table 3).

\section{DISCUSSION}

Literature has shown that childhood asthma is more common in boys, possibly due to physiologically narrower airways and increased muscle tone, which is lost after 10 years of age while girls are more frequently affected by teenage asthma [7]. The results of our research indicated that asthma was more common in boys.

Inadequate knowledge of parents about oral deseases in children with asthma and prevention resulted in an increased incidence of oral diseases. Based on the recent

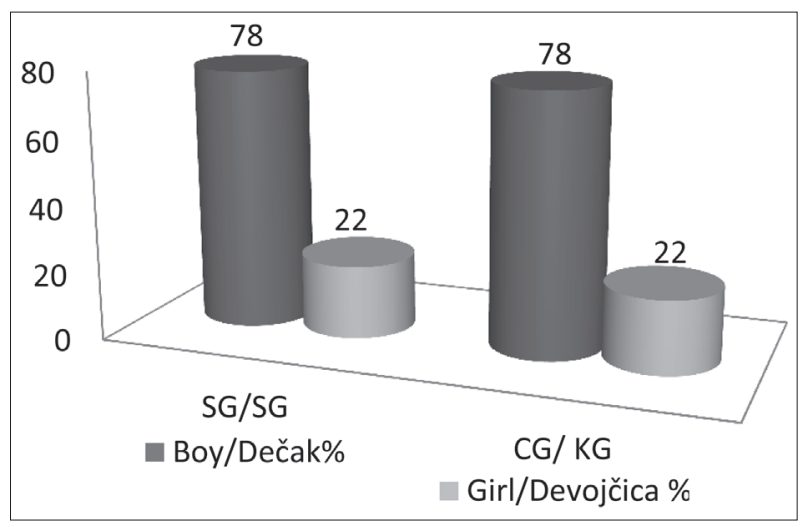

Figure 1. Distribution of children by gender

Grafikon 1. Distribucija dece po polu

SG - Study group, CG - Control group

SG - studijska grupa, KG - kontrolna grupa

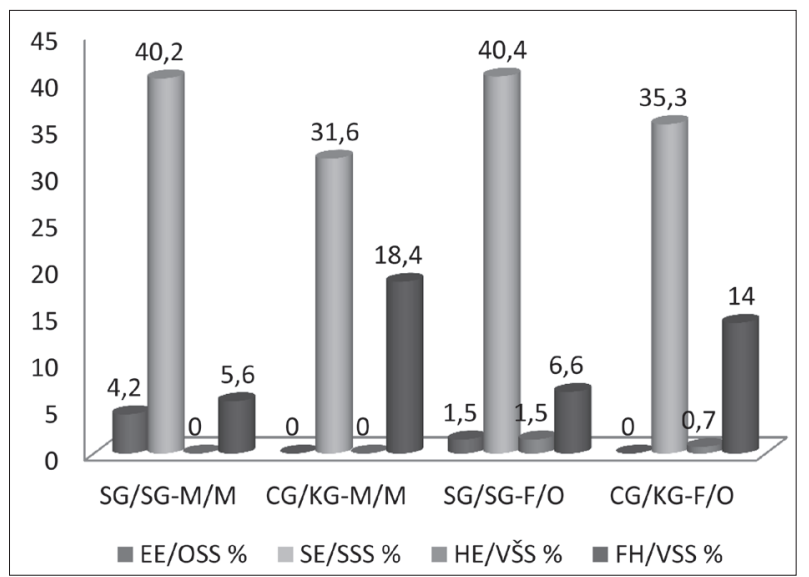

Figure 2. Distribution of parent's education Grafikon 2. Distribucija školske spreme roditelja

SG - Study group, CG - Control group, M - mother, F - father, EE - elementary education, $\mathrm{SE}$ - secondary education, $\mathrm{HE}$ - higher education, $\mathrm{FE}$ - faculty education SG - studijska grupa, KG - kontrolna grupa, M - majka, O - otac, OSS - osnovno obrazovanje, SSS - srednjoškolsko obrazovanje, VŠS - visokoškolsko obrazovanje, VSS - fakultetsko obrazovanje 
Table 1. Oral hygiene and dietary related habits in the observed groups

Tabela 1. Oralno-higijenske i dijetetske navike kod ispitivanih grupa

\begin{tabular}{|c|c|c|c|c|c|}
\hline $\begin{array}{l}\text { Question } \\
\text { Pitanje }\end{array}$ & $\begin{array}{l}\text { Answer } \\
\text { Odgovor }\end{array}$ & $\begin{array}{c}\text { SG/SG (\%) } \\
N=68\end{array}$ & $\begin{array}{c}\text { CG/KG (\%) } \\
N=68\end{array}$ & $\begin{array}{l}\text { AR/SI (\%) } \\
N=136\end{array}$ & $\mathbf{P}$ \\
\hline \multirow{3}{*}{$\begin{array}{l}\text { 1. To maintain oral hygiene you use? } \\
\text { Šta koristiš za održavanje oralne higijene? }\end{array}$} & $\begin{array}{l}\text { Toothbrush and toothpaste } \\
\text { Četkicu i pastu za zube }\end{array}$ & 82.4 & 66.2 & 74.3 & \multirow{3}{*}{$<0.05$} \\
\hline & $\begin{array}{l}\text { Toothbrush, toothpaste, floss } \\
\text { Četkicu i pastu za zube, konac }\end{array}$ & 7.4 & 7.4 & 7.4 & \\
\hline & $\begin{array}{l}\text { Toothbrush, toothpaste, mouthwash } \\
\text { Četkicu i pastu za zube, tečnost }\end{array}$ & 10.3 & 26.5 & 18.4 & \\
\hline \multirow{3}{*}{$\begin{array}{l}\text { 2. How often you brush your teeth? } \\
\text { Koliko često pereš zube? }\end{array}$} & $\begin{array}{l}\text { Less than once per day } \\
\text { Manje od jednom dnevno }\end{array}$ & 6.0 & 0.0 & 6.0 & \multirow{3}{*}{$<0.05$} \\
\hline & $\begin{array}{l}\text { Once a day } \\
\text { Jednom dnevno }\end{array}$ & 34.8 & 22.8 & 28.8 & \\
\hline & $\begin{array}{l}\text { Several times a day } \\
\text { Nekoliko puta dnevno }\end{array}$ & 60.2 & 77.2 & 68.7 & \\
\hline \multirow{4}{*}{$\begin{array}{l}\text { 3. When do you brush your teeth? } \\
\text { Kada pereš zube? }\end{array}$} & $\begin{array}{l}\text { In the morning } \\
\text { Ujutro }\end{array}$ & 18.6 & 6.6 & 12.6 & \multirow{4}{*}{$>0.05$} \\
\hline & $\begin{array}{l}\text { Before going to bed } \\
\text { Pre odlaska u krevet }\end{array}$ & 23.8 & 13.4 & 18.6 & \\
\hline & $\begin{array}{l}\text { In the morning and in the evening } \\
\text { Ujutro i pre odlaska u krevet }\end{array}$ & 51.8 & 57.8 & 54.8 & \\
\hline & $\begin{array}{l}\text { In the morning, in the afternoon, in the evening } \\
\text { Ujutro, popodne i pre odlaska u krevet }\end{array}$ & 5.8 & 22.2 & 14.0 & \\
\hline \multirow{4}{*}{$\begin{array}{l}\text { 4. How long do you brush your teeth? } \\
\text { Koliko dugo pereš zube? }\end{array}$} & $\begin{array}{l}\text { Less than } 1 \text { minute } \\
\text { Manje od jednog minuta }\end{array}$ & 14.7 & 8.8 & 11.8 & \multirow{4}{*}{$<0.05$} \\
\hline & $\begin{array}{l}1 \text { minute } \\
\text { Jedan minut }\end{array}$ & 29.4 & 17.6 & 23.5 & \\
\hline & $\begin{array}{l}2 \text { minutes } \\
\text { Dva minuta }\end{array}$ & 36.8 & 35.3 & 36.0 & \\
\hline & $\begin{array}{l}\text { More than } 2 \text { minutes } \\
\text { Duže od dva minuta }\end{array}$ & 19.1 & 38.2 & 28.7 & \\
\hline \multirow{4}{*}{$\begin{array}{l}\text { 5. My parents ... } \\
\text { Moji roditelji me... }\end{array}$} & $\begin{array}{l}\text { Supervise me while I brush my teeth } \\
\text { Nadgledaju dok perem zube }\end{array}$ & 20.6 & 28.0 & 24.3 & \multirow{4}{*}{$>0.05$} \\
\hline & $\begin{array}{l}\text { Do not supervise, but advise } \\
\text { Ne nadgledaju, ali savetuju }\end{array}$ & 33.8 & 38.2 & 36.0 & \\
\hline & $\begin{array}{l}\text { Never supervise } \\
\text { Nikad ne nadgledaju }\end{array}$ & 14.7 & 5.8 & 10.3 & \\
\hline & $\begin{array}{l}\text { Only mother supervise } \\
\text { Samo majka nadgleda }\end{array}$ & 30.9 & 27.9 & 29.4 & \\
\hline \multirow{5}{*}{$\begin{array}{l}\text { 6. How often do you consume sweets? } \\
\text { Koliko često jedeš slatkiše? }\end{array}$} & $\begin{array}{l}\text { Once a day } \\
\text { Jednom dnevno }\end{array}$ & 30.9 & 32.4 & 31.6 & \multirow{5}{*}{$>0.05$} \\
\hline & $\begin{array}{l}\text { Once a week } \\
\text { Jednom nedeljno }\end{array}$ & 2.9 & 4.4 & 3.7 & \\
\hline & $\begin{array}{l}\text { Several times a day } \\
\text { Nekoliko puta dnevno }\end{array}$ & 54.4 & 44.1 & 49.3 & \\
\hline & $\begin{array}{l}\text { Several times a week } \\
\text { Nekoliko puta nedeljno }\end{array}$ & 10.3 & 17.6 & 14.0 & \\
\hline & $\begin{array}{l}\text { I do not eat sweets } \\
\text { Ne jedem slatkiše }\end{array}$ & 1.5 & 1.5 & 1.5 & \\
\hline \multirow{5}{*}{$\begin{array}{l}\text { 7. How often do you drink sweet drinks? } \\
\text { Koliko često piješ slatke napitke? }\end{array}$} & $\begin{array}{l}\text { Once a day } \\
\text { Jednom dnevno }\end{array}$ & 30.9 & 26.5 & 28.7 & \multirow{5}{*}{$>0.05$} \\
\hline & $\begin{array}{l}\text { Once a week } \\
\text { Jednom nedeljno }\end{array}$ & 10.3 & 10.3 & 10.3 & \\
\hline & $\begin{array}{l}\text { Several times a day } \\
\text { Nekoliko puta dnevno }\end{array}$ & 45.6 & 45.6 & 45.6 & \\
\hline & $\begin{array}{l}\text { Several times a week } \\
\text { Nekoliko puta nedeljno }\end{array}$ & 11.8 & 13.2 & 12.5 & \\
\hline & $\begin{array}{l}\text { I do not drink sweet drinks } \\
\text { Ne pijem slatke napitke }\end{array}$ & 1.5 & 4.4 & 2.9 & \\
\hline
\end{tabular}

SG - Study group; CG - Control group; AR - All respondents; $N$ - number of respondents; $\mathrm{P}$ - statistical significance (Pearson Chi-Square $\chi 2)$; $\%$ - percentage of the respondents

SG - studijska grupa; KG - kontrolna grupa; SI - svi ispitanici; N - broj ispitanika; P - statistička značajnost (Pearson Chi-Square $\chi 2$ ); \% - procenat ispitanika 
Table 2. Oral health related knowledge in the investigated groups

Tabela 2. Stečena znanja u vezi sa oralnim zdravljem kod ispitivanih grupa

\begin{tabular}{|c|c|c|c|c|c|}
\hline $\begin{array}{l}\text { Question } \\
\text { Pitanje }\end{array}$ & $\begin{array}{l}\text { Answer } \\
\text { Odgovor }\end{array}$ & $\begin{array}{l}\text { SG/SG (\%) } \\
\mathrm{N}=\mathbf{6 8}\end{array}$ & $\begin{array}{c}\text { CG/KG (\%) } \\
\mathbf{N}=\mathbf{6 8}\end{array}$ & $\begin{array}{c}A R / S I(\%) \\
N=136\end{array}$ & $\mathbf{P}$ \\
\hline \multirow{4}{*}{$\begin{array}{l}\text { 1. What does bleeding of the gums mean? } \\
\text { Šta znači kada krvare desni? }\end{array}$} & \begin{tabular}{|l|} 
Healthy gums \\
Zdrave desni \\
\end{tabular} & 1.5 & 2.9 & 2.2 & \multirow{4}{*}{$>0.05$} \\
\hline & $\begin{array}{l}\text { Diseased gums } \\
\text { Bolesne desni }\end{array}$ & 58.8 & 55.9 & 57.4 & \\
\hline & \begin{tabular}{|l|} 
Gums recession \\
Povlačenje desni \\
\end{tabular} & 0.0 & 2.9 & 1.5 & \\
\hline & $\begin{array}{l}\text { I do not know } \\
\text { Ne znam }\end{array}$ & 39.7 & 38.2 & 39.0 & \\
\hline \multirow{4}{*}{$\begin{array}{l}\text { 2. How to protect yourself against the } \\
\text { occurrence of bleeding gums? } \\
\text { Kako se zaštititi od nastanka krvarenja } \\
\text { desni? }\end{array}$} & $\begin{array}{l}\text { By the use of toothbrush and pastes } \\
\text { Upotrebom četkice i paste }\end{array}$ & 38.2 & 35.3 & 36.8 & \multirow{4}{*}{$>0.05$} \\
\hline & \begin{tabular}{|l|} 
By the use of soft food \\
Upotrebom mekane hrane
\end{tabular} & 2.9 & 5.9 & 4.4 & \\
\hline & $\begin{array}{l}\text { By the use of vitamin } C \\
\text { Upotrebom vitamina } C\end{array}$ & 4.4 & 11.8 & 8.1 & \\
\hline & $\begin{array}{l}\text { I do not know } \\
\text { Ne znam }\end{array}$ & 54.4 & 47.1 & 50.7 & \\
\hline \multirow{4}{*}{$\begin{array}{l}\text { 3. What are teeth deposits? } \\
\text { Šta su to naslage na zubima? }\end{array}$} & $\begin{array}{l}\text { Soft deposits on the teeth } \\
\text { Meke nečistoće na zubima }\end{array}$ & 35.3 & 23.5 & 29.4 & \multirow{4}{*}{$>0.05$} \\
\hline & $\begin{array}{l}\text { Dirty teeth } \\
\text { Prljavi zubi }\end{array}$ & 19.1 & 10.3 & 14.7 & \\
\hline & \begin{tabular}{|l|} 
Hard deposits on the teeth \\
Tvrde nečistoće na zubima \\
\end{tabular} & 16.2 & 22.1 & 19.1 & \\
\hline & $\begin{array}{l}\text { I do not know } \\
\text { Ne znam }\end{array}$ & 29.4 & 44.1 & 36.8 & \\
\hline \multirow{5}{*}{$\begin{array}{l}\text { 4. The presence of teeth deposits leads to... } \\
\text { Prisutne naslage na zubima dovode do... }\end{array}$} & $\begin{array}{l}\text { Gingivitis } \\
\text { Upale desni }\end{array}$ & 4.4 & 2.9 & 3.7 & \multirow{5}{*}{$>0.05$} \\
\hline & \begin{tabular}{|l|} 
Dirty teeth \\
Prljavih zuba
\end{tabular} & 16.2 & 8.8 & 12.5 & \\
\hline & \begin{tabular}{|l} 
Tooth decay \\
Karijesa zuba
\end{tabular} & 19.1 & 17.6 & 18.4 & \\
\hline & $\begin{array}{l}\text { I do not know } \\
\text { Ne znam }\end{array}$ & 50.0 & 45.6 & 47.8 & \\
\hline & $\begin{array}{l}\text { Gingivitis and dental caries } \\
\text { Upale desni i zubnog karijesa }\end{array}$ & 10.3 & 25.0 & 17.6 & \\
\hline \multirow{5}{*}{$\begin{array}{l}\text { 5. How do you rate your oral health? } \\
\text { Kako ocenjuješ svoje oralno zdravlje? }\end{array}$} & $\begin{array}{l}\text { Good } \\
\text { Dobro }\end{array}$ & 45.6 & 75.0 & 60.3 & \multirow{5}{*}{$<0.001$} \\
\hline & \begin{tabular}{|l|} 
Satisfactorily \\
Zadovoljavajuće
\end{tabular} & 19.1 & 14.7 & 16.9 & \\
\hline & $\begin{array}{l}\text { Average } \\
\text { Prosečno }\end{array}$ & 20.6 & 5.9 & 13.2 & \\
\hline & $\begin{array}{l}\text { Neither good nor bad } \\
\text { Ni dobro ni loše }\end{array}$ & 11.8 & 2.9 & 7.4 & \\
\hline & $\begin{array}{l}\text { Bad } \\
\text { Loše }\end{array}$ & 2.9 & 1.5 & 2.2 & \\
\hline
\end{tabular}

SG - Study group; CG - Control group; AR - All respondents; $\mathrm{N}$ - number of respondents; $\mathrm{P}$ - statistical significance (Pearson Chi-Square $\chi 2$ ); \% - Percentage of the respondents SG - studijska grupa; KG - kontrolna grupa; $\mathrm{SI}$ - svi ispitanici; $\mathrm{N}$ - broj ispitanika; P - statistička značajnost (Pearson Chi-Square $\chi 2$ ); $\%$ - procenat ispitanika

Table 3. Oral health related behavior in observed groups

Tabela 3. Ponašanje prema oralnom zdravlju kod ispitivanih grupa

\begin{tabular}{|c|c|c|c|c|c|}
\hline $\begin{array}{l}\text { Question } \\
\text { Pitanje }\end{array}$ & $\begin{array}{l}\text { Answer } \\
\text { Odgovor }\end{array}$ & $\begin{array}{c}S G / S G(\%) \\
N=68\end{array}$ & $\begin{array}{c}\mathrm{CG} / \mathrm{KG}(\%) \\
\mathrm{N}=\mathbf{6 8}\end{array}$ & $\begin{array}{c}A R / S I(\%) \\
N=136\end{array}$ & $\mathbf{P}$ \\
\hline \multirow{6}{*}{$\begin{array}{l}\text { 1. Did anybody talked to you } \\
\text { about the importance of } \\
\text { maintaining mouth and } \\
\text { teeth healthy? } \\
\text { Da li ti je neko pričao o } \\
\text { važnosti očuvanja zdravlja } \\
\text { usta i zuba? }\end{array}$} & \begin{tabular}{|l} 
Parent \\
Roditelj
\end{tabular} & 55.9 & 61.8 & 58.8 & \multirow{6}{*}{$>0.05$} \\
\hline & $\begin{array}{l}\text { Teacher } \\
\text { Nastavnik }\end{array}$ & 2.9 & 0.0 & 1.5 & \\
\hline & \begin{tabular}{|l|} 
Dentist \\
Stomatolog \\
\end{tabular} & 16.2 & 16.2 & 16.2 & \\
\hline & \begin{tabular}{|l|} 
Family doctor \\
Porodični lekar \\
\end{tabular} & 1.5 & 0.0 & 0.7 & \\
\hline & \begin{tabular}{|l|} 
None \\
Niko \\
\end{tabular} & 4.4 & 2.9 & 3.7 & \\
\hline & $\begin{array}{l}\text { Parents and dentists } \\
\text { Roditelji i stomatolog }\end{array}$ & 19.1 & 19.2 & 19.1 & \\
\hline
\end{tabular}




\begin{tabular}{|c|c|c|c|c|c|}
\hline \multirow{4}{*}{$\begin{array}{l}\text { 2. How often do you visit } \\
\text { your dentist? } \\
\text { Koliko često posećuješ } \\
\text { svog stomatologa? }\end{array}$} & $\begin{array}{l}\text { Regularly } \\
\text { Redovno }\end{array}$ & 30.9 & 52.9 & 41.9 & \multirow{4}{*}{$<0.01$} \\
\hline & $\begin{array}{l}\text { Periodically } \\
\text { Ponekad }\end{array}$ & 50.0 & 29.4 & 39.7 & \\
\hline & $\begin{array}{l}\text { When I have toothache } \\
\text { Kada me boli zub }\end{array}$ & 11.8 & 14.7 & 13.2 & \\
\hline & $\begin{array}{l}\text { I have never visited the dentist } \\
\text { Nikad nisam bio kod stomatologa }\end{array}$ & 7.4 & 2.9 & 5.1 & \\
\hline \multirow{5}{*}{$\begin{array}{l}\text { 3. The last time you visited } \\
\text { the dentist? } \\
\text { Zadnji put si posetio/la } \\
\text { stomatologa... }\end{array}$} & $\begin{array}{l}\text { I have not been at the dentist } \\
\text { until now } \\
\text { Nisam bio dosad }\end{array}$ & 7.4 & 2.9 & 5.1 & \multirow{5}{*}{$<0.01$} \\
\hline & $\begin{array}{l}\text { Before } 6 \text { months } \\
\text { Pre } 6 \text { meseci }\end{array}$ & 63.2 & 58.8 & 61.0 & \\
\hline & $\begin{array}{l}6-12 \text { months } \\
6-12 \text { meseci }\end{array}$ & 13.2 & 32.4 & 22.8 & \\
\hline & $\begin{array}{l}1-2 \text { years } \\
1-2 \text { godine }\end{array}$ & 14.7 & 2.9 & 8.8 & \\
\hline & $\begin{array}{l}\text { In last } 2-5 \text { years } \\
2-5 \text { godina }\end{array}$ & 1.5 & 2.9 & 2.2 & \\
\hline \multirow{5}{*}{$\begin{array}{l}\text { 4. How many times have } \\
\text { you visited a dentist in } \\
\text { last year? } \\
\text { Koliko puta si posetio/la } \\
\text { stomatologa u protekloj } \\
\text { godini? }\end{array}$} & $\begin{array}{l}\text { Not once } \\
\text { Nijednom }\end{array}$ & 20.6 & 10.3 & 15.4 & \multirow{5}{*}{$>0.05$} \\
\hline & $\begin{array}{l}\text { Once } \\
\text { Jednom }\end{array}$ & 19.1 & 16.2 & 17.6 & \\
\hline & $\begin{array}{l}\text { Two times } \\
\text { Dva puta }\end{array}$ & 11.8 & 17.6 & 14.7 & \\
\hline & $\begin{array}{l}\text { Three times } \\
\text { Tri puta }\end{array}$ & 22.1 & 14.7 & 18.4 & \\
\hline & $\begin{array}{l}\text { Four and more times } \\
\text { Četiri i više puta }\end{array}$ & 26.5 & 41.2 & 33.8 & \\
\hline \multirow{6}{*}{$\begin{array}{l}\text { 5. Treatment that you had } \\
\text { during the last visit to the } \\
\text { dentist? } \\
\text { Tretman koji si imao/la } \\
\text { u toku poslednje posete } \\
\text { stomatologu? }\end{array}$} & $\begin{array}{l}\text { I have not been at the dentist until now } \\
\text { Nisam bio dosad kod stomatologa }\end{array}$ & 7.4 & 2.9 & 5.1 & \multirow{6}{*}{$>0.05$} \\
\hline & $\begin{array}{l}\text { Examination or fluoridation of teeth } \\
\text { Pregled ili fluorisanje zuba }\end{array}$ & 39.7 & 51.5 & 45.6 & \\
\hline & $\begin{array}{l}\text { Orthodontic treatment } \\
\text { Ortodontski tretman }\end{array}$ & 4.4 & 2.9 & 3.7 & \\
\hline & $\begin{array}{l}\text { Gum treatment } \\
\text { Lečenje desni }\end{array}$ & 5.9 & 1.5 & 3.7 & \\
\hline & $\begin{array}{l}\text { Fillings } \\
\text { Postavljanje plombe }\end{array}$ & 23.5 & 20.6 & 22.1 & \\
\hline & $\begin{array}{l}\text { Tooth extraction } \\
\text { Vađenje zuba }\end{array}$ & 19.1 & 20.6 & 19.9 & \\
\hline \multirow{5}{*}{$\begin{array}{l}\text { 6. If you do not visit a dentist } \\
\text { or you are afraid to go to } \\
\text { him/her the reason is? } \\
\text { Ako ne posećuješ } \\
\text { stomatologa ili se bojiš ići } \\
\text { kod njega, razlog je? }\end{array}$} & $\begin{array}{l}\text { I'm afraid of dental needles } \\
\text { Bojim se stomatološke igle }\end{array}$ & 13.2 & 7.4 & 10.3 & \multirow{5}{*}{$<0.001$} \\
\hline & $\begin{array}{l}\text { I'm uncomfortable due to sound of machines } \\
\text { Neprijatno mi je zbog zvuka mašine }\end{array}$ & 0.0 & 2.9 & 1.5 & \\
\hline & $\begin{array}{l}\text { Since there is no toothache, there is no need to go to the dentist } \\
\text { Pošto nema zubobolje, nema potrebe ići stomatologu }\end{array}$ & 13.2 & 8.8 & 11.0 & \\
\hline & $\begin{array}{l}\text { I'm afraid to even think about a scheduled appointment at the dentist } \\
\text { Bojim se čak i razmišljati o zakazanom pregledu kod stomatologa }\end{array}$ & 19.1 & 2.9 & 11.0 & \\
\hline & $\begin{array}{l}\text { I am not afraid of going to the dentist } \\
\text { Ne bojim se odlaska kod stomatologa }\end{array}$ & 54.4 & 77.9 & 66.2 & \\
\hline
\end{tabular}

SG - Study group; CG - Control group; AR - All respondents; $\mathrm{N}$ - number of respondents; $\mathrm{P}$ - statistical significance (Pearson Chi-Square $\chi 2$ ); $\%$ - percentage of the respondents SG - studijska grupa; KG - kontrolna grupa; $\mathrm{SI}$ - svi ispitanici; $\mathrm{N}$ - broj ispitanika; P - statistička značajnost (Pearson Chi-Square $\chi 2$ ); $\%$ - procenat ispitanika

study conducted in Croatia, parents can influence their children in terms of oral hygiene maintainance [3]. The study in Iran demonstrated that mothers who took good oral hygiene, transfer their knowledge and attitudes to their children [8]. The level of education and parents incomes influence the incidence of oral diseases $[9,10]$. In this study, it was observed that mothers in the study group had lower education than mothers in the control group.

Proper and regular oral hygiene includes daily, often and long enough teeth brushing, as well as application of some additional hygiene methods. Children often do not understand the importance of brushing their teeth [11].
Efficient removal of dental plaque is crucial for the health of teeth and periodontal tissues. Proper habits, attitudes and behavior toward oral health are best to be established in childhood. The results of this research showed that children in the study group irregularly maintain hygiene, do not brush long enough, and mostly use toothbrush and toothpaste only. Unlike our study, research conducted in Sweden showed that there was no difference in oral hygiene maintainince habits between children with and without asthma [12]. Studies of Mazzoleni et al. and Eloot et al. showed that children with asthma had better oralhygiene habits than healthy control group $[13,14]$. 
Adequate oral hygiene of parents and supervision of children when brushing their teeth are important predictors of good oral health [15]. Supervision of children should be conducted up to 10 years of children's age, until their manual skills are sufficiently developed to properly brush teeth. The results of our study showed that children in the study group were less supervised than children from control group. One of the possible explanations for this phenomenon could be greater devotion of parents to their children's basic illness.

If everyday diet often includs sweet foods, especially between meals, combined with improper oral hygiene maintenance, there is great chance of tooth decay appearance. Analyzing the results of the current study, it was noted that children in the study group consumed more sweets or drunk sweet drinks several times a day. However, frequent consumption of candy and beverage in this group of children did not indicate statistically significant difference in relation to the control group. The results of our research are in accordance with Stensson at al. [12]. Similar eating habits were also reported in children from the experimental and control groups in the study conducted by Mazzoleni at al. in Italy [13]. On the other hand, children with asthma from Belgium consumed less sweets [14]. Higher consumption of non-alcoholic drinks rich in sugars was observed in subjects with asthma from South Australia [16], and Norway [17] compared to their healthy peers. Parents of children with asthma should be adequately educated about possible oral health problems related to food and drinks consumption, especially after inhalation, the importance of fluoride use and maintaining oral hygiene. In some countries, parents of children suffering from asthma in hospital conditions take greater care and attention to improving their children's oral hygiene habits, and thus better control of the disease [14].

Poor oral hygiene and periodontal disease may increase the incidence of lung infections in risky patients. Oral cavity has been considered a potential reservoir for respiratory infections microorganisms as dental plaque may trap respiratory pathogenic microorganisms [18]. Good oral health is important not only to prevent oral diseases but also to maintain good respiratory function. Mechanical removal of soft deposits reduces the number of gram-negative bacteria that also helps keep airways open in children with asthma [19]. Knowledge about dental plaque of all subjects from both groups in our study was poor.

Our study indicated that children with asthma understood the importance of oral health and stated their oral health was not at satisfactory level. However, they visited dentist mainly when they had a specific problem. Studies have confirmed that children who practice dental visits more frequently are better informed about mouth and teeth health [20].

Regular dental checkups should be performed at least twice a year. However, if a person has potentially higher risk of developing oral disease, as seen in asthma [2], examinations should be more frequent. The result of our questionnaire suggested that children with asthma only occasionally went to dentist. Toothache was one of the main reasons for visiting dentist $[20,21,22]$, rarely check- up or tooth restoration. These findings are consistant with results of other studies [22,23].

Wogelius at al. in their research found more frequent presence of dental anxiety in children with asthma [24]. It was more pronounced in younger children [24]. In our study, children with asthma had greater degree of fear even just in planning their visit to the dentist, as well as possible use of dental needles that would cause dental visits delay. Delaying dental visits on the other hand would increase dental fear creating vicious circle [25].

The role of the dentist in advising parents about adequate way to apply preventative measures and preserve oral health has undeniable significance as children acquire first knowledge, attitudes or habits about oral health importance from parents [20].

\section{CONCLUSION}

Children with asthma have partially developed oral hygiene habits compared to healthy children. Also, their level of knowledge and behavior toward their own oral health is not adequate. Fear of dental interventions is one limiting factor. For successful dental treatment of children with asthma, good communication skills are important given their previous experience (being in hospital due to asthma, injection therapy, ongoing checkups). It is necessary to emphasize the importance of the first contact with dentist in the earliest age, primarily due to acquisition of positive habits, as well as introduction of preventive measures.

\section{REFERENCES}

1. Cover RA, Fleischer DM, Boguniewicz M. Allergic disorders. In: Hay Jr. WW, Levin MJ, Deterding RR, Abzug MJ, Sondheimer JM, editors. Current diagnosis and treatment pediatrics. 21st ed. New York: McGraw Hill; 2012.

2. Thomas MS, Parolia A, Kundabala M, Vikram M. Asthma and oral health: a review. Aust Dent J. 2010; 55(2):128-33. [DOI: 10.1111/j.1834-7819.2010.01226.x] [PMID: 20604752]

3. Beljan M, Puharić Z, Žulec M, Borić D, Neumuller KR. Znanje o oralnom zdravlju i zdravstveno ponašanje roditelja i djece školskog uzrasta. Acta Med Croatica. 2016; 70: 165-71.

4. Vodanović M. Strah od stomatologa. Zdrav život. 2008; 57(7):66-70.

5. Priya SL, Moses J, Rangeeth BN, Sivakumar S. Dental Fear under Rated Yet Significant. Int J Dent Sci Res. 2014; 2(4A):12-4. [DOI: 10.12691/ijdsr-2-4A-4]

6. Carrillo-Diaz M, Crego A, Armfield JM, Romero-Maroto M. Treatment experience, frequency of dental visits, and children's dental fear: a cognitive approach. Eur J Oral Sci. 2012; 120:75-81. [DOI: 10.1111/j.1600-0722.2011.00921.x] [PMID: 22288924]

7. Ivković-Jureković I. Specifičnosti astme dječje dobi. Medicus. 2013; 22(1):43-8.

8. Mohebbi S, Virtanen Jl, Murtomaa H, Vehkalahti MM. Mothers as facilitators of oral hygiene in early childhood. Int J Paediatr Dent. 2008; 18:48-55. [DOI: 10.1111/j.1365-263X.2007.00861.x] [PMID: 18086026]

9. Miller E, Lee JY, DeWalt DA, Vann WFJr. Impact of caregiver literacy on children's oral health outcomes. Pediatrics. 2010; 126(1):107-14. [DOI: 10.1542/peds.2009-2887] [PMID: 0547644]

10. Radović I, Davidović L, Krunić J, Stojanović N. Stanje zuba u odnosu na socioekonomske faktore i protetički status kod osoba starije životne dobi u Republici Srpskoj. Stom Glas Srb. 2015; 62(1):14-20. [DOl: 10.1515/sdj-2015-0002] 
11. Gill P, Stewart K, Chetcuti D, Chestnutt IG. Children's understanding and motivations for toothbrushing: a qualitative study. Int I Dent Hyg. 2011; 9(1):79-86. [DOI: 10.1111/j.1601-5037.2010.00442.x.] [PMID: 21226855]

12. Stensson M, Wendt L.-K, Koch G, Oldaeus G, Lingström P, Birkhed D. Caries Prevalence, Caries-Related Factors and Plaque $\mathrm{pH}$ in Adolescents with Long-Term Asthma. Caries Res. 2010; 44:540-6. [DOI: 10.1159/000321566] [PMID: 21051892]

13. Mazzoleni S, Stellini E, Cavaleri E, Volponi AA, Ferro R, Colombani SF. Dental caries in children with asthma undergoing treatment with short-acting ß2-agonists. Eur J Paediatr Dent. 2008; 9(3):132-8. [PMID: 18844442]

14. Eloot AK, Vanobbergen JN, De Baets F, Martens LC. Oral health and habits in children with asthma related to severity and duration of condition. Eur J Paediatr Dent. 2004; 5(4):210-5. [PMID: 15606319]

15. Lalić $M$, Aleksić E, Gajić M, Malešević $Đ$. Oral health related knowledge and health behavior of parents and school children. Med Pregl. 2013; 66(1-2):70-9. [DOI: 10.2298/MPNS1302070L] [PMID: 23534304]

16. Shi Z, Dal Grande E, Taylor AW, Gill TK, Adams R, Wittert GA. Association between soft drink consumption and asthma and chronic obstructive pulmonary disease among adults in Australia. Respirology. 2012; 17(2):363-9. [DOI: 10.1111/j.14401843.2011.02115.x.] [PMID: 22142454]

17. Bueso AK, Berntsen S, Mowinckel P, Andersen LF, Lødrup Carlsen KC, Carlsen K-H. Dietary intake in adolescents with asthma - potential for improvement. Pediatr Allergy Immunol. 2011; 22:19-24. [DOI: 10.1111/j.1399-3038.2010.01013.x] [PMID: 20961335]

18. Scannapieco FA, Ho AW. Potential associations between chronic respiratory disease and periodontal disease: Analysis of National
Health and Nutrition Examination Survey III. J Periodontol. 2001; 72(1):50-6. [DOI: 10.1902/jop.2001.72.1.50] [PMID: 11210073]

19. Pambudi W, Fabiola I, Indrawati R, Utomo H, Endaryanto A, Harsono A. Changes in bacterial profiles after periodontal treatment associated with respiratory quality of asthmatic children. Paediatrica Indonesiana.2008; 48(6):327-38. [DOI: 10.14238/pi48.6. 2008.327-37]

20. Davidović B, Ivanović $M$, Janković S, Lečić J. Informisanost, stavovi i ponašanje djece prema oralnom zdravlju. Vojnosanit pregl. 2014; 71(10):949-56. [DOI: 10.2298/VSP130714034D] [PMID: 25518275]

21. Al-Omiri MK, Al-Wahadni AM, Saeed KN. Oral Health Attitudes, Knowledge, and Behavior Among School Children in North Jordan. J Dent Educ. 2006; 70(2):179-87. [PMID: 16478932]

22. Obradović $M$, Dolić $O$. Caries prevalence and risk factors for its development in urban and rural regions. Stom Glas S. 2008; 55(1):3442. [DOI: $10.2298 /$ SGS0801034O]

23. Prasad AKP, Shankar S, Sowmya J, Priyaa CV. Oral health Knowledge Attitude Practice of School students of KSR Matriculation School, Thiruchengode. J Ind Aca Dent Spec. 2010; 1(1):5-11.

24. Wogelius P, Poulsen S, Srrrensen HT. Asthma, ear problems, and dental anxiety among 6- to 8-yr-olds in Denmark: a populationbased cross-sectional study. Eur J Oral Sci. 2003; 111(6):472-6. [PMID: 14632682]

25. Armfield JM. What goes around comes around: revisiting the hypothesized vicious cycle of dental fear and avoidance. Community Dent Oral Epidemiol. 2013; 41(3):279-87. [DOI: 10.1111/ cdoe.12005] [PMID: 23004917] 


\title{
Oralnohigijenske navike kod dece obolele od astme
}

\author{
Bojana Davidović1, Mirjana Ivanović2, Dejan Bokonjić3, Svjetlana Janković1, Igor Radović ${ }^{1}$ Jelena Lečić1 \\ 'Univerzitet u Istočnom Sarajevu, Medicinski fakultet, Studijski program Stomatologija, Foča, Bosna i Hercegovina; \\ ${ }^{2}$ Stomatološki fakultet, Klinika za dečju i preventivnu stomatologiju, Beograd, Srbija; \\ ${ }^{3}$ Univerzitetska bolnica u Foči, Klinika za pedijatriju, Foča, Bosna i Hercegovina
}

\begin{abstract}
KRATAK SADRŽAJ
Uvod Cilj ovog istraživanja je bio da se na osnovu upitnika ispita poznavanje oralnohigijenskih navika, znanja i ponašanja vezanog za oralno zdravlje dece sa astmom.

Metode rada $U$ istraživanje je uključeno 136 dece uzrasta od 6 do 16 godina, podeljenih u dve grupe. Prvu - studijsku grupu (SG) - činila su deca sa astmom, dok su u drugu - kontrolnu grupu (KG) - bila uključena zdrava deca. Za potrebe istraživanja kreiran je anketni upitnik koji je sadržavao tri grupe pitanja: oralnohigijenske i dijetetske navike, znanje, te ponašanje dece prema oralnom zdravlju.

Rezultati Najveći procenat dece studijske grupe (60,2\%) zube četka više puta u toku dana u odnosu na 77,2\% dece kontrolne grupe $(p<0,05)$. Duže od dva minuta četka $19,1 \%$ dece studijske, odnosno $38,2 \%$ kontrolne grupe $(p<0,05)$. Nije bilo značajne razlike $u$ nivou znanja o značaju i uticaju plaka na oralno zdravlje između grupa ( $p>0,05)$. Veća polovina $(52,9 \%)$ kontrolne grupe redovno posećuje stomatologa, dok $50 \%$ studijske to čini povremeno $(\mathrm{p}<0,001)$. Kao razlog zadnje posete stomatologu, preventivnu kontrolu je navelo 51,5\% dece kontrolne grupe, dok su deca studijske grupe dolazila uglavnom zbog sanacije zuba (42,6\%). Strah od stomatoloških intervencija bio je izražajniji kod dece studijske u odnosu na kontrolnu grupu $(p<0,001)$.

Zaključak Oralnohigijenske navike i ponašanje u vezi sa oralnim zdravljem bili su lošiji kod dece sa astmom, dok nije bilo razlike $u$ nivou stečenih znanja kada su ispitivane grupe u pitanju.

Ključne reči: deca; astma; oralnohigijenske navike; znanja; oralna higijena
\end{abstract}

\section{UVOD}

Astma predstavlja hroničnu zapaljensku bolest disajnih puteva, koja uglavnom započinje već u detinjstvu. Nakon što se izlože određenim podražajima, disajni putevi se zbog grča muskulature, čepova sluzi i otoka sluznice sužavaju, a protok vazduha postaje ograničen. Ovo je jedan od vodećih razloga hospitalizacije u dečjem uzrastu [1].

Terapijska procedura astme ima za cilj ili da ublaži simptome ili da deluje protivupalno. Literaturni navodi ukazuju da neki od antiasmatskih lekova utiču na promenu sastava i količine pljuvačke, tako da su obolele osobe izložene većem riziku od karijesa, erozijama na zubima, povećanoj prevalenci promena na oralnoj sluznici, gingivitisima, parodontopatijama, orofagealnoj kandidijazi, kao i orofacijalnim nepravilnostima [2]. Zbog svega navedenog, deca kojima je dijagnostikovana astma zahtevaju veću pažnju, jer mogu biti rizična grupa za nastanak oralnih oboljenja.

Zbog važnosti oralne higijene u dečjem uzrastu, mnoga istraživanja su rađena na temu prepoznavanja faktora rizika koji mogu dovesti do nastanka oralnih oboljenja. Literaturni navodi ukazuju kako se navike roditelja u vezi sa oralnim zdravljem prenose na decu i tako direktno ili indirektno utiču na pojavu karijesa kod dece [3].

Strah od stomatoloških intervencija prisutan je kod velikog broja ljudi nezavisno od starosti, pola, stepena fizičke i mentalne zrelosti, stepena obrazovanja, ekonomskog statusa, zanimanja, a kad je reč o deci, osim pomenutog, i od odnosa roditelja prema stomatološkom tretmanu $[4,5]$. Kod dece prisustvo „straha od stomatologa " predstavlja najčešći razlog za izbegavanje tretmana, zbog čega izostaje odgovarajuća stomatološka zaštita, što može dovesti do pogoršanja oralnog zdravlja $[5,6]$.

Imajući u vidu da neke stomatološke intervencije mogu biti stresne, da jaki mirisi u stomatološkoj ambulanti mogu provocirati asmatski napad, kao i zbog blizine gornjih disajnih puteva, pacijenti sa hroničnim respiratornim problemima, kakva je astma, predstavljaju pacijente sa rizikom. Akutni asmatični napad može da predstavlja jedan od faktora koji povećavaju strah od odlaska stomatologu, kao i da utiče na model ponašanja dece sa astmom prema oralnom zdravlju.

Cilj ovog istraživanja je bio da se na osnovu upitnika ispita poznavanje oralnohigijenskih navika, stečenih znanja i ponašanja vezanog za oralno zdravlje dece sa astmom.

\section{METODE RADA}

Istraživanje je obavljeno na odseku Stomatologija, Medicinskog fakulteta Univerziteta u Istočnom Sarajevu, a prema preporukama Helsinške deklaracije i principima Dobre kliničke prakse. Roditelji i deca su informisana o svrsi istraživanja i dobijena je pismena saglasnost roditelja za učešće u istom.

Istraživanje predstavlja studiju preseka koja je obuhvatila decu starosti od 6 do 16 godina $(10,49 \pm 3,28)$. Celokupni uzorak od 136 dece podeljen je u dve grupe. Studijsku grupu (SG) $(n=68)$ činila su deca kojima je dijagnostikovana astma. Kontrolnu grupu $(\mathrm{KG})(\mathrm{n}=68)$ predstavljala su zdrava deca, $\mathrm{tj}$. ona kod kojih nisu uočeni znaci bilo kog hroničnog oboljenja. Dijagnoza astme je postavljena od strane nadležnog pedijatra ili lekara porodične medicine, na osnovu sledećih kriterijuma: postojanja tipičnih simptoma astme, nalaza spirometrije, reakcije na lekove za astmu (reverzibilnost opstrukcije), postojanja alergije, pozitivne porodične anamneze, nepostojanja drugih stanja koja mogu da daju slične simptome ili znake [1]. Studija je dizajnirana tako da deca iz kontrolne grupe prema polu i uzrastu odgovaraju deci iz studijske grupe.

Za potrebe ovog istraživanja kreiran je anketni upitnik, koji je sadržavao tri grupe pitanja: o oralnohigijenskim i dijetetskim navikama, stečenim znanjima koja deca imaju u odnosu na oralno zdravlje te formiranim navikama ponašanja kad je reč o posetama stomatologu.

Dobijeni podaci u toku ovog ispitivanja su numerički obrađeni standardnim statističkim procedurama u statističkom 
programu SPSS 19,0 za Windows. Za testiranje razlike između polova, stepena stručne spreme roditelja, anketnih pitanja po grupama posmatranja upotrebljen je $\chi^{2}$ test. Vrednosti $\mathrm{p}<0,05$ smatrane su statistički značajnim.

\section{REZULTATI}

Astma je češće dijagnostikovana kod dečaka $(77,9 \%)$ u odnosu na devojčice $(22,1 \%)(\mathrm{p}<0,05)$ (Grafikon 1$)$. Stečena visoka $(18,4 \%)$ i srednja stručna sprema $(31,6 \%)$ bila je zastupljenija kod majki dece iz kontrolne grupe, u odnosu na stečeno osnovno $(4,2 \%)$ ili srednje obrazovanje $(39,7 \%)$ majki dece studijske grupe . Ali značajna razlika nije uočena (Grafikon 2).

Skoro $83 \%$ dece studijske grupe za održavanje oralne higijene koristi samo četkicu i pastu za zube u odnosu na decu kontrolne grupe, koja uz osnovna sredstva za higijenu upotrebljavaju još tečnosti za ispiranje usta (26,5\%) (Tabela 1). Deca studijske grupe u najvećem procentu $(60,2 \%)$ zube peru više puta u toku dana, dok deca kontrolne grupe tu naviku upražnjavaju u procentu od 77,2. Roditelji češće kontrolišu decu kontrolne grupe dok održavaju oralnu higijenu (28\%), u odnosu na roditelje dece studijske grupe (20,6\%). Oko 15\% dece studijske grupe roditelji ne pomažu niti nadziru pranje zuba. I jedna i druga grupa vole da konzumiraju slatkiše i zaslađene napitke, s tim da to čine u većem procentu deca studijske grupe ( $\mathrm{p}>0,05)$ (Tabela 1$)$.

Dobro oralno zdravlje prema sopstvenoj proceni navelo je $45,6 \%$ deca studijske, odnosno $75 \%$ dece kontrolne grupe $(\mathrm{p}<0,001)$ (Tabela 2).

$\mathrm{U}$ najvećem procentu, na redovne preglede kod stomatologa odlazi 52,9\% dece kontrolne grupe, dok 50\% dece studijske grupe povremeno odlazi stomatologu $(\mathrm{p}<0,01)$ (Tabela 3$)$. $U$ studijskoj grupi 7,4\% dece dosad nikad nisu bili kod stomatologa, u odnosu na 2,9\% dece iz kontrolne grupe. Deca iz kontrolne grupe $(51,5 \%)$ kao glavni razlog posete stomatologu navode preventivne razloge, dok su se deca studijske grupe u najvećem broju slučajeva $(42,6 \%)$ obratila zbog sanacije zuba. Strah od stomatoloških intervencija bio je izražajniji kod dece studijske grupe u odnosu na kontrolnu $(\mathrm{p}<0,001)$. Saznanja o važnosti oralnog zdravlja deca studijske grupe u najvećem procentu dobijala su od roditelja $(55,9)$, dok su te vrednosti iznosile $61,8 \%$ kod dece kontrolne grupe (Tabela 3 ).

\section{DISKUSIJA}

Literaturni navodi pokazuju da je astma u detinjstvu češća kod dečaka, verovatno zbog fiziološki užih disajnih puteva te povećanog mišićnog tonusa, koji se gubi nakon desete godine života, dok u pubertetu od astme češće obolevaju devojčice [7]. Rezultati našeg istraživanja ukazuju da je astma bila zastupljenija kod dečaka.

Nedovoljna upućenost roditelja o samom oboljenju i načinima prevencije rezultiraju povećanom incidencom pojave oralnih oboljenja kod dece sa astmom. Na osnovu nedavno sprovedene studije u Hrvatskoj utvrđeno je da roditelji mogu uticati na svoje dete u pogledu održavanja oralne higijene [3]. Studija u Iranu je ukazala da majke koje brinu o ličnoj oralnoj higijeni prenose svoje znanje i stavove na decu [8]. Nivo obra- zovanja i prihodi roditelja takođe utiču na incidencu nastanka oralnih oboljenja $[9,10]$. U ovom istraživanju je uočeno da su majke dece studijske grupe imale niže obrazovanje u odnosu na majke dece iz kontrolne grupe.

Pravilna i redovna oralna higijena podrazumeva svakodnevno, često i dovoljno dugo četkanje zuba, kao i primenu nekih od dodatnih sredstava za higijenu. Deca često nemaju jasnu predstavu o tome zašto je neophodno da peru zube [11]. Efikasno uklanjanje dentalnog plaka presudno je za zdravlje zuba i parodontalnih tkiva. Pravilne navike, stavovi i ponašanje prema oralnom zdravlju najbolje se uspostavljaju u detinjstvu. Rezultati ovog istraživanja su pokazali da deca iz studijske grupe neredovno održavaju higijenu, to čine nedovoljno dugo, i uglavnom upotrebljavaju samo četkicu i pastu za zube. Za razliku od naše studije, jedno istraživanje sprovedeno u Švedskoj je ukazalo na nepostojanje razlika u navikama u održavanju oralne higijene između dece sa astmom i dece bez astme [12]. Studije Mazzoleni i sar., kao i Eloot i sar. pokazale su da su deca sa astmom imala bolje oralnohigijenske navike u odnosu na zdravu kontrolnu grupu $[13,14]$.

Adekvatna oralna higijena roditelja i navika da kontrolišu dete pri pranju zuba su značajni prediktori dobrog oralnog zdravlja deteta [15]. Kontrola dece u toku održavanja oralne higijene od strane roditelja trebalo bi da postoji do desete godine života, odnosno do momenta kad su njihove manuelne spretnosti dovoljno razvijene da mogu samostalno korektno izvršiti ovu dosta komplikovanu veštinu „pravilnog četkanja zuba“. Rezultati ovog istraživanja pokazuju da su deca studijske grupe u većem procentu bila bez roditeljskog nadzora kad je reč o kontroli oralne higijene. Kao jedno od mogućih objašnjenja za ovu pojavu mogla bi biti veća posvećenost roditelja osnovnom oboljenju svog deteta.

Ukoliko se u lancu svakodnevne ishrane nađe često unošenje zaslađene hrane, posebno između obroka, udruženo sa nepravilnim održavanjem oralne higijene, velika je šansa da će se kod osobe pojaviti karijes. Analizom rezultata ovog istraživanja primećeno je da deca studijske grupe češće konzumiraju slatkiše ili piju slatke napitke, što čine i po nekoliko puta u toku dana. Međutim, učestala konzumacija slatkiša i napitaka kod ove grupe dece nije ukazala na statistički značajnu razliku u pojavi karijesa u odnosu na kontrolu. Rezultati našeg istraživanja u skladu su sa istraživanjem Stenssona i sar. [12]. Slične prehrambene navike imala su deca iz eksperimentalne i kontrolne grupe studije sprovedene od strane Mazzoleni i sar. u Italiji [13]. S druge strane, vršnjaci sa astmom iz Belgije konzumirali su u manjem procentu slatkiše [14]. Veća potrošnja bezalkoholnih pića bogatih šećerima uočena je kod ispitanika sa astmom iz Južne Australije [16], ali i kod dečaka iz Norveške koji boluju od astme [17] u odnosu na zdrave vršnjake.

Deca sa astmom, kao i njihovi roditelji, trebalo bi da budu adekvatno upoznati sa mogućim oralnozdravstvenim tegobama vezanim za količinu i učestalost konzumacije pića i hrane (posebno nakon inhalacije), upotrebi fluorida i redovnoj higijeni. $\mathrm{U}$ pojedinim zemljama roditelji dece koja se leče od astme u bolničkim uslovima pridaju veću brigu i pažnju svojoj deci u cilju poboljšanja oralnohigijenskih navika, pa samim tim i bolje kontrole bolesti [14].

Loša oralna higijena i parodontopatije mogu uticati na učestalost plućnih infekcija kod rizičnih pacijenata. Usna duplja se smatra potencijalnim rezervoarom za mikroorganizme respiratornih infekcija, jer dentalni plak može služiti kao skladište 
respiratornih patogenih mikroorganizama [18]. Dobro oralno zdravlje je važno ne samo da bi se sprečila oboljenja usta već i da bi se održao dobar kvalitet respiratorne funkcije. Mehaničkim uklanjanjem mekih naslaga smanjuje se broj gram-negativnih bacila, a time se poboljšava kvalitet disajnih puteva dece sa astmom [19].Znanje ispitanika iz obe ispitivane grupe ove studije, procenjivano anketnim upitnikom, bilo je na niskom nivou kad je reč o informacijama o dentalnom plaku.

Ovo ispitivanje ukazalo je na činjenicu da kod dece sa astmom postoji razvijena svest o sopstvenom oralnom zdravlju, $i$ izjasnili su se da njihovo oralno zdravlje nije na zadovoljavajućem nivou. Međutim, iako su toga svesni, stomatologa posećuju uglavnom kad imaju konkretan problem. Istraživanja potvrđuju da su deca koja češće posećuju stomatologa bolje informisana o zdravlju usta i zuba [20].

Redovne stomatološke preglede trebalo bi organizovati najmanje dva puta godišnje. Međutim, ako je osoba u potencijalno većem riziku za nastanak oralnih oboljenja, kao što je to uočeno kod dece obolele od astme [2], preglede bi trebalo organizovati češće. Rezultat ovog anketnog upitnika govori u prilog tome da deca sa astmom povremeno odlaze kod stomatologa. Zubobolja je jedan od glavnih razloga posete dece stomatologu $[20,21,22]$, nešto ređe su to kontrolni pregledi ili sanacije zuba [22, 23], a deca sa astmom se u znatnoj meri rukovode takvom praksom.

Wogelius i sar. su u svom istraživanju ukazali na češće prisustvo dentalne anksioznosti kod dece koja boluju od astme [24].
Ona je bila više izražena kod mlađe dece [24]. Na osnovu analize ovog istraživanja deca sa astmom su pokazala veći stepen straha i pri samoj pomisli o zakazanom odlasku kod stomatologa, odnosno mogućoj upotrebi stomatološke igle. Ova vrsta straha je često značajan ograničavajući faktor koji vodi odgađanju poseta stomatologu. Na taj način se samo pojačava strah od stomatoloških intervencija i stvara začarani krug [25].

Uloga stomatologa u savetovanju dece i roditelja u pronalaženju adekvatnog načina za primenu preventivnih mera u očuvanju oralnog zdravlja su od neprocenjivog značaja [20]. Ova studija je ukazala da većina dece prva saznanja, stavove ili navike o važnosti oralnog zdravlja stiču od roditelja, a ne od stomatologa.

\section{ZAKLJUČAK}

Deca sa astmom imaju delimično razvijene oralnohigijenske navike u odnosu na zdravu decu, ali nivo saznanja i ponašanje prema sopstvenom oralnom zdravlju nisu odgovarajući. Strah od stomatoloških intervencija je takođe jedan od ograničavajućih faktora. Za uspešan stomatološki tretman dece sa astmom važna je, pre svega, dobra komunikacija sa stomatologom, koji treba da svojim pozitivnim stavom olakša komunikaciju i ukaže na značaj održavanja oralne higijene, odnosno predloži uvođenje preventivnih mera kod dece sa astmom. 